\title{
Infection of the cockle Cerastoderma edule in the Baie des Veys (France) by the microsporidian parasite Steinhausia sp.
}

\author{
Thierry Comtet $^{1,2, *}$, Céline Garcia ${ }^{1,3}$, Yvette Le Coguic ${ }^{1}$, Jean-Pierre Joly ${ }^{1,3}$ \\ ${ }^{1}$ Laboratoire Conchylicole de Bretagne, IFREMER, Station de la Trinité-sur-Mer, 12 rue des résistants, \\ BP 26, 56470 La Trinité-sur-Mer, France \\ ${ }^{2}$ UMR CNRS-UPMC 7127, Equipe Ecologie Benthique, Station Biologique, BP 74, 29682 Roscoff Cedex, France \\ ${ }^{3}$ Laboratoire Génétique et Pathologie, IFREMER, Station de la Tremblade, Ronce-les-Bains, BP 133, 17390 La Tremblade, France
}

\begin{abstract}
We report the occurrence of the microsporidian parasite Steinhausia sp. in the oocytes of the common cockle Cerastoderma edule in a natural population in France, where high mortalities occurred. Steinhausia sp. appeared primarily as sporocysts containing many small spores, and putative earlier developmental stages were also observed. Both its prevalence and infection intensity were low, and no host defence reaction was recognized, suggesting that Steinhausia sp. had no detrimental effect on $C$. edule. Its prevalence was higher in cockles lying on the sediment surface, but the significance of this observation could not be explained given the poor knowledge of the Steinhausia life cycle. The present data did not allow specific identification of the parasite, and further studies are required to determine whether Steinhausia sp. in the cockle is a new species, or a microsporidian infecting multiple host species.
\end{abstract}

KEY WORDS: Cerastoderma edule $\cdot$ Steinhausia sp. Microsporida $\cdot$ Oocyte $\cdot$ Baie des Veys

\section{INTRODUCTION}

The common cockle Cerastoderma edule (L.) is a suspension-feeding bivalve mainly distributed in the soft-bottom intertidal areas of numerous bays and estuaries in western Europe, where it lives buried in the sediment (a few $\mathrm{cm}$ depth). In bays where the species is abundant, natural populations are commercially exploited, but cockles are also occasionally cultured. In France, cockle production (1400 t yr-1, FAO 2000) is mainly from natural populations distributed along both the Atlantic and English Channel coasts.

Numerous parasites have been reported in Cerastoderma edule (Bower et al. 1994, Azevedo 1997, Carballal et al. 2001), including microsporidians in the epithelial cells of the digestive gland (Comps et al. 1975). Microsporidians have been recorded in various tissues of numerous marine bivalve species: haemocytes forming aggregates in the connective tissue of the digestive gland of the scallop Aequipecten opercularis (Lohrmann et al. 2000); connective tissue surrounding the gut epithelium of the oyster Ostrea lutaria (Jones 1981); stomach epithelium of the clams Ruditapes decussatus, Venerupis pullastra and $V$. rhomboides (Villalba et al. 1993a,b); and digestive gland epithelium in the scallop Chlamys varia (Bodoy et al. 1991). In addition, microsporidians belonging to Steinhausia spp. have been described as infecting the oocytes of the European flat oyster O. edulis (Léger \& Hollande 1917), the mytilid mussels Mytilus galloprovincialis and M. edulis (Field 1923, Sprague 1965, Figueras et al. 1991), the Sydney rock oyster Saccostrea commercialis (Anderson et al. 1995), and the clams Macoma balthica (Farley 1977) and V. pullastra (Villalba et al. 1993a,b).

More recently, a Steinhausia-like microsporidian was identified in the oocytes of Cerastoderma edule from 2 populations in Galicia (NW Spain), with both 
low prevalence (1 in 30 individuals were infected in each population) and low infection intensity (few oocytes were infected) (Carballal et al. 2001). We report herein the identification of a Steinhausia sp. microsporidian in $C$. edule from a natural population in the Baie des Veys, France.

\section{MATERIALS AND METHODS}

In the Baie des Veys (Fig. 1), natural populations of Cerastoderma edule are harvested, with an annual production ranging between 100 and 500 t (M. Letrouvé and P. Le Roland, Direction Départementale des Affaires Maritimes de la Manche and du Calvados, Directions Départementales, respectively, pers. comm.). In August 2001, high mortalities (up to $70 \%$ ) were observed. As part of the sampling strategy of the French monitoring network REPAMO (IFREMER), which investigates the causes of mortalities observed in French production areas, 6 samples of ca. 30 living cockles each were collected on August 17, 2001 in order to evaluate their histopathological state. Three stations were sampled twice in the mortality area (Fig. 1), with 1 sample composed of cockles lying on

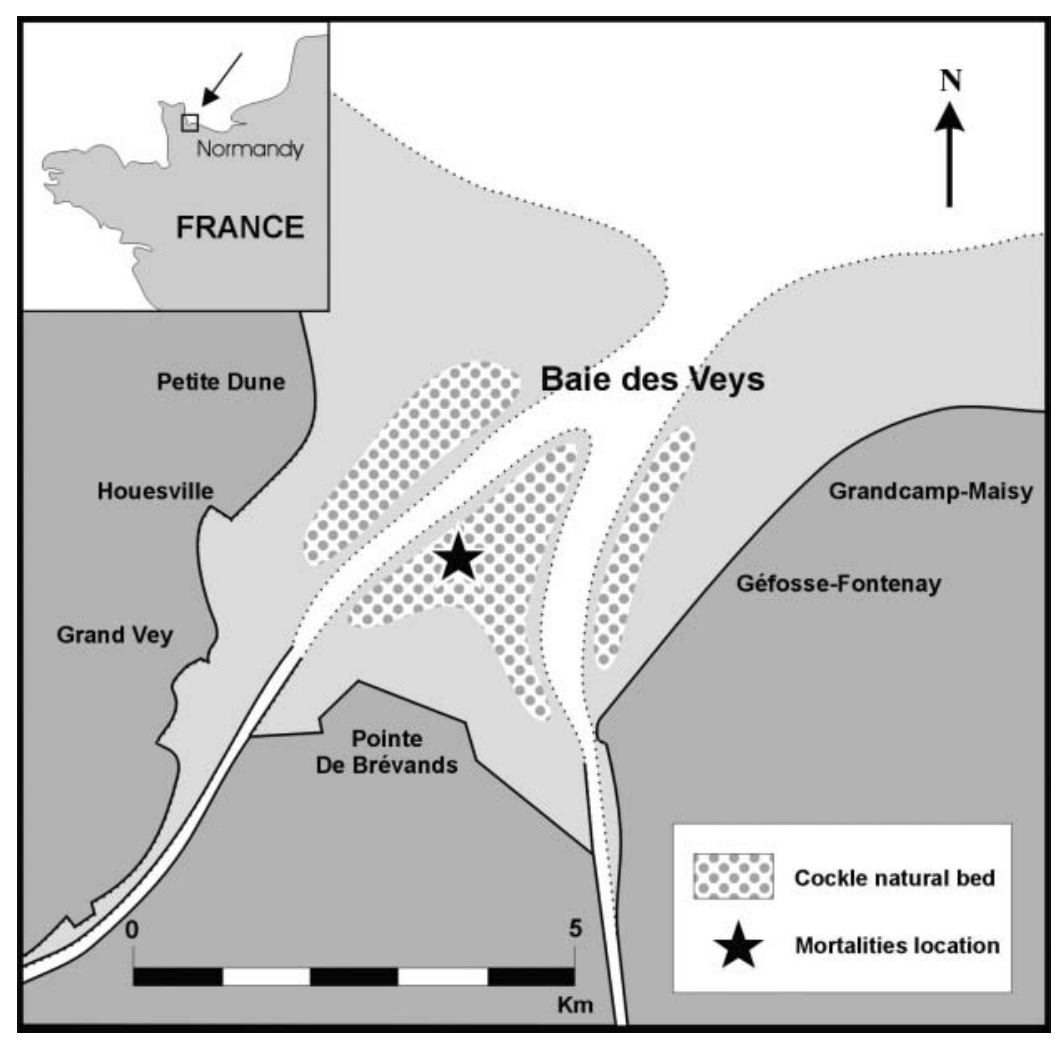

Fig. 1. Location of the sampled cockle bed in the Baie des Veys, France. 'Mortalities location' shows the area where mortalities occurred the surface of the sediment ('surface' cockles) and 1 composed of cockles buried in the sediment ('buried' cockles).

Preliminary observations of whole-mount gonadal tissue of 23 additional specimens revealed the occurrence of a Steinhausia-like parasite in the oocytes. To study the extent of the parasite infection in the population, we carefully examined histological sections. Individuals were dissected and tissues fixed for $24 \mathrm{~h}$ in Davidson's fixative (Shaw \& Battle 1957), and then dehydrated and embedded in paraffin. Sections (2 to $3 \mu \mathrm{m}$ thick) were cut, stained with hematoxylin-eosin and examined with light microscopy for the presence of Steinhausia sp.

Prevalence is defined as the percentage of host individuals in a sample infected by a particular parasite species (Bush et al. 1997). Due to their location in the oocytes, Steinhausia microsporidians infect only females or hermaphrodites. Thus, although we also examined males, prevalence of the Steinhausia sp. infection was calculated only from female data (no hermaphrodite was encountered), as described by Villalba et al. (1997) for S. mytilovum in the mussel Mytilus galloprovincialis. In addition, only cases with sporocyst stages were considered, because identification of early developmental stages is not certain. The prevalence of the Steinhausia sp. infection between buried and surface cockles was compared using the non-parametric Wilcoxon-Mann-Whitney test (Scherrer 1984).

\section{RESULTS}

A Steinhausia-like microsporidian parasite (referred to as Steinhausia sp. from this point) was recorded in the oocytes of 18 female Cerastoderma edule. The most abundant form of the parasite appeared as cysts containing many spores, the cysts being limited by a more or less thick membrane (Fig. 2) that was sometimes difficult to detect. Sporocysts were usually elliptical to circular in shape, with a size ranging from 16 to $31 \mu \mathrm{m}$ (mean = $20.68 \mu \mathrm{m}, \mathrm{SD}=4.06 \mu \mathrm{m}, \mathrm{N}=13$ ), containing up to 30 spores. Spores were almost spherical, with a diameter ranging from 2 to $3.2 \mu \mathrm{m}$ (mean = $2.56 \mu \mathrm{m}, \mathrm{SD}=0.35 \mu \mathrm{m}, \mathrm{N}=73$ ). The cysts were primarily located in the oocyte cytoplasm, with a single exam- 
ple (i.e. $3 \%$ ) being observed inside the nucleus (Fig. 3). Two oocytes (i.e. 6\% of the infected oocytes) showed multiple infections, with 2 sporocysts per oocyte (Fig. 4). Distortion of the nuclear membrane due to the presence of a parasite in the cytoplasm was observed once (i.e. in a single oocyte). In a single case, a sporocyst was observed in a degraded oocyte (Fig. 5). In addition, putative other developmental stages were observed, including an early developmental stage (Fig. 6) and plasmodial stages contain- ing numerous nuclei (Fig. 7). In no cases were major haemocyte infiltration associated with the infection. The intensity of infection was low, commonly with 1 to 5 infected oocytes per slide.

The prevalence of the Steinhausia sp. infection ranged from 11.8 to $20 \%$ in buried and surface cockles, respectively (Table 1). The non-parametric WilcoxonMann-Whitney test indicated that prevalence was significantly higher in surface Cerastoderma edule (unilateral test, $\mathrm{p}=0.05$ ).
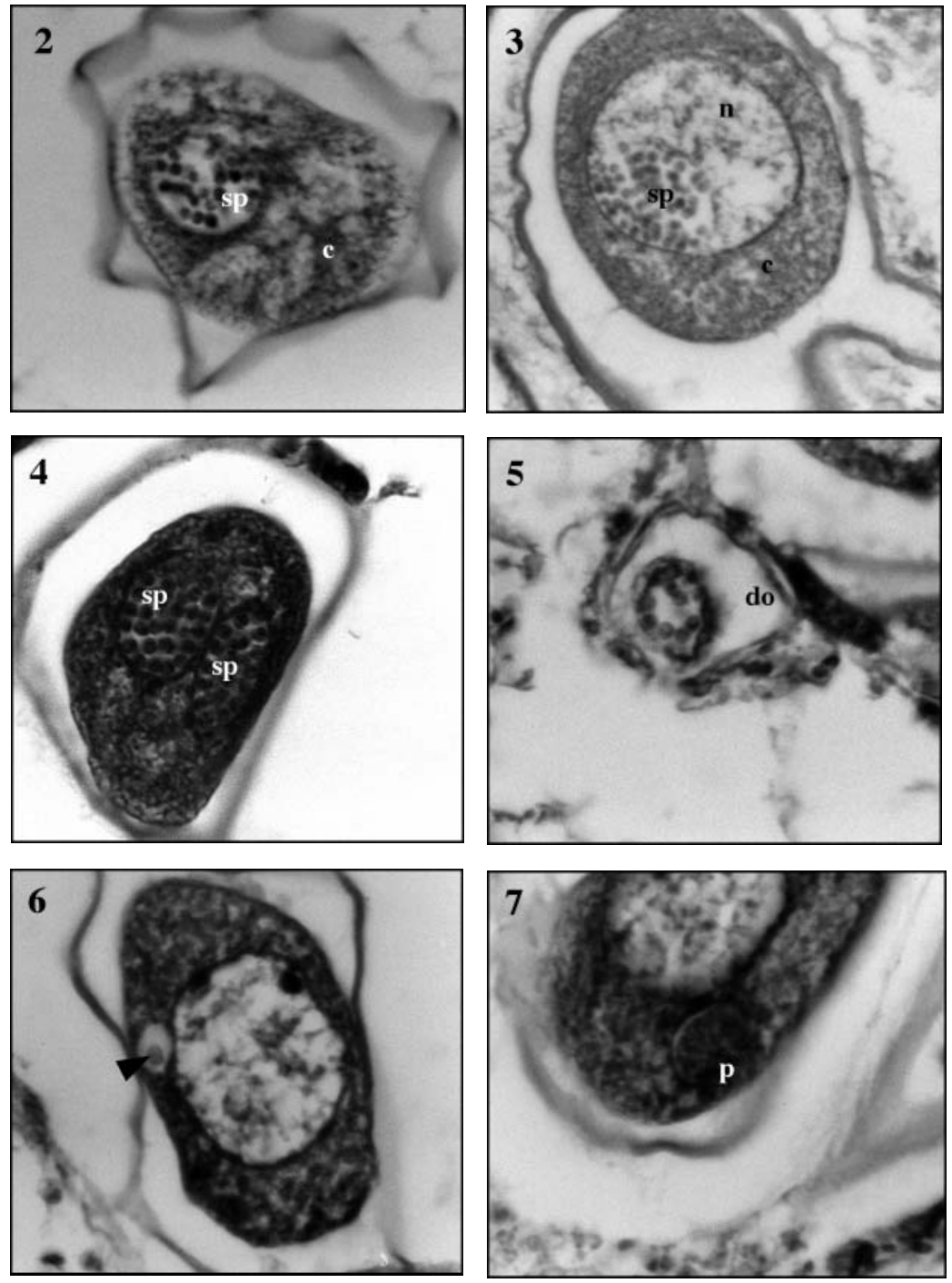

Figs. 2 to 7. Steinhausia sp. in the oocytes of the common cockle Cerastoderma edule. Histological sections in the gonadal tissue stained with hematoxylineosin $(750 \times)$. Fig. 2. Sporocyst (sp) containing numerous spores in the cytoplasm (c) of an oocyte. Fig. 3. Sporocyst in the nucleus (n) of an oocyte. Fig. 4. Multiple infection with 2 sporocysts in the cytoplasm of a single oocyte. Fig. 5. Sporocyst within an apparently degraded oocyte (do). No cytoplasm is observed. Fig. 6. Putative early developmental stage (arrowhead) of Steinhausia sp. in the cytoplasm. Fig. 7. Putative plasmodial stage (p) of Steinhausia sp. in the cytoplasm

\section{DISCUSSION}

A Steinhausia sp. microsporidian parasite in the oocytes of Cerastoderma edule has been recorded for the first time in France. It was similar to that observed by Carballal et al. (2001) in C. edule from Spain, and also to the other different species of Steinhausia described to date. It occurred mainly as sporocysts containing many small spores. Spore sizes (2 to $3.2 \mu \mathrm{m}$ ) were in the range of those of Steinhausia spp. in C. edule from Spain (ca. $1.5 \mu \mathrm{m}$ ) (Carballal et al. 2001), Saccostrea commercialis from Australia (1.7 to $4.1 \mu \mathrm{m}$ ) (Anderson et al. 1995), Ostrea edulis from France $(2.3 \mu \mathrm{m})$ (Léger \& Hollande 1917), Mytilus galloprovincialis from Spain (1.5 to $2.5 \mu \mathrm{m}$ ) (Villalba et al. 1997, Sagristà et al. 1998), and M. edulis from the USA (3 $\mu \mathrm{m}$, but spores as large as 6 to $8 \mu \mathrm{m}$ were observed in fresh smears of gonadal tissue) (Sprague 1965). Infection by Steinhausia sp. in C. edule can be single or multiple (with 2 sporocysts in a single oocyte), as observed for other Steinhausia species (Léger \& Hollande 1917, Sprague 1965, Anderson et al. 1995, Villalba et al. 1997). Sporocysts were mainly located in the oocyte cytoplasm, but were occasionally observed inside the nucleus, as already observed for S. mytilovum (de Vincentiis \& Renzoni 1963, Sprague 1970, Sagristà et al. 1998). In the cytoplasm, we observed the parasite inducing an invagination of the nuclear membrane, but less frequently than in S. mytilovum, in which sporocysts are usually closely associated with the host-cell nucleus (Sprague 1965). Earlier developmental 
Table 1. Steinhausia sp. infection in the common cockle Cerastoderma edule. Prevalence of the parasite in females from 3 stations and 2 sediment positions (buried and surface) from the Baie des Veys. Only sporocysts were considered in the calculations, identification of earlier stages being not certain

\begin{tabular}{|ccccc|}
\hline Stn & $\begin{array}{c}\text { Sediment } \\
\text { position }\end{array}$ & $\begin{array}{c}\text { Number of } \\
\text { females }\end{array}$ & $\begin{array}{c}\text { Number of } \\
\text { infected females }\end{array}$ & $\begin{array}{c}\text { Prevalence } \\
(\%)\end{array}$ \\
\hline 1 & Surface & 20 & 4 & 20.0 \\
& Buried & 18 & 3 & 16.7 \\
2 & & & 2 & 20.0 \\
& Surface & 10 & 2 & 11.8 \\
3 & Buried & 17 & 3 & 20.0 \\
& & & 4 & 18.2 \\
\hline
\end{tabular}

transmission (Desclaux et al. 2002), with the parasite reducing the burrowing efficiency of its host (Jonsson \& André 1992, Jensen et al. 1999). Unfortunately, in the present case the significance of differential infection for Steinhausia sp. in Cerastoderma edule could not be established due to the lack of knowledge of the parasite life-cycle and mode of transmission.

Our observation raises the question of species identification of Steinhausia sp. in Cerastoderma edule, and the possibility that $S$. mytilovum infects multiple host species, occuring with other microsporidian species (Pashara-

stages of the parasite were also observed, similar to those reported for $S$. mytilovum in $M$. galloprovincialis (e.g. see Fig. 2 in Sagristà et al. 1998).

The prevalence of the Steinhausia sp. infection in Cerastoderma edule from the Baie des Veys (11.8 to $20 \%$ of the females were infected, which equals 6.3 to $13.3 \%$ of the total number of sampled individuals) was higher than that in $C$. edule from Galicia (3.3\% of the collected cockles), but in this latter case, the proportion of males and females was not known (Carballal et al. 2001). Our values were in the range of those observed for S. mytilovum in Mytilus galloprovincialis from Galicia ( 7.5 to $28.3 \%$ of females) (Figueras et al. 1991, Villalba et al. 1997), but prevalence of up to $76 \%$ of females was reported in M. galloprovincialis from the Black Sea (Rybakov \& Kholodkovskaya 1987). This low prevalence, associated with low intensity of infection, suggests that Steinhausia sp. probably had no lethal impact on cockles, and was not the main cause of the mortality observed in the analyzed populations. Moreover, no major haemocyte infiltration was observed, a reaction sometimes reported in Steinhausia spp. infections in M. galloprovincialis (Figueras et al. 1991, Villalba et al. 1997) and Saccostrea commercialis (Anderson et al. 1995). Our results did not allow us to evaluate the effect of Steinhausia sp. in C. edule. However, the parasite could affect the viability of the infected oocytes and cockle fecundity, as hypothesized for S. mytilovum in M. galloprovincialis (Field 1923, Figueras et al. 1991, Robledo et al. 1994, Villalba et al. 1997). The observation of a sporocyst inside a degraded oocyte supports this hypothesis.

Prevalence of infection was higher in surface females (non-parametric Wilcoxon-Mann-Whitney test, $p=0.05$ ). Such a difference in infection levels between buried and surface cockles has already been shown for other parasites, including larval stages of digenean trematodes (Desclaux et al. 2002). In some digenean infections, this phenomenon could facilitate parasite wipas et al. 1994, Fries et al. 2001). Indeed, Mytilus edulis and $M$. galloprovincialis from both natural and cultured populations located close to the Baie des Veys are infected by $S$. mytilovum (T. Comtet et al. unpubl.). The same situation is encountered at Illa de Arousa in Galicia, where S. mytilovum has been recorded in M. galloprovincialis (Figueras et al. 1991, Villalba et al. 1997), and where C. edule is infected with Steinhausia sp. (Carballal et al. 2001). To answer this question would require either a transmission electron microscopy examination of the spore ultrastructure, which we could not conduct in the present work because of the low intensity of infection, or the development of molecular tools for species identification (Berthe et al. 1999).

Acknowledgements. We are indebted to J. Kopp (IFREMER, Station de Port-en-Bessin), the Directions Départementales des Affaires Maritimes de la Manche and du Calvados for collecting samples and for providing us with fisheries statistics. We acknowledge A. Thébault (IFREMER, Station de La Tremblade), coordinator of the REPAMO program, for her assistance, and M.-A. Lekkas for improving the English. Three anonymous reviewers provided helpful comments on the manuscript. This work was supported by IFREMER and CNRS.

\section{LITERATURE CITED}

Anderson TJ, Hine PM, Lester RJG (1995) A Steinhausia-like infection in the ovocytes of Sydney rock oysters Saccostrea commercialis. Dis Aquat Org 22:143-146

Azevedo C (1997) Some observations on an amoeba, destructive agent of the gills of Cerastoderma edule (Mollusca, Bivalvia). Dis Aquat Org 30:223-225

Berthe FCJ, Burreson EM, Hine PM (1999) Use of molecular tools for mollusc disease diagnosis. Bull Eur Assoc Fish Pathol 19:277-278

Bodoy A, Garnier J, Heurtebise S, Nollet V, Chagot D (1991) Diversification des productions conchylicoles en PoitouCharentes: l'élevage du pétoncle noir Chlamys varia. Report No. RIDRV-91-11-RA/LA TREMBLADE. IFREMER, La Tremblade 
Bower SM, McGladdery SE, Price IM (1994) Synopsis of infectious diseases and parasites of commercially exploited shellfish. Annu Rev Fish Dis 4:1-199

Bush AO, Lafferty KD, Lotz JM, Shostak AW (1997) Parasitology meets ecology on its own terms: Margolis et al. revisited. J Parasitol 83:575-583

Carballal MJ, Iglesias D, Santamarina J, Ferro-Soto B, Villalba A (2001) Parasites and pathologic conditions of the cockle Cerastoderma edule populations of the coast of Galicia (NW Spain). J Invertebr Pathol 78:87-97

Comps M, Grizel H, Tigé G, Duthoit JL (1975) Parasites nouveaux de la glande digestive des mollusques marins Mytilus edulis L. et Cardium edule L. CR Acad Sci Paris D 281:179-181

Desclaux C, de Montaudouin X, Bachelet G (2002) Cockle emergence at the sediment surface: 'favourization' mechanism by digenean parasites? Dis Aquat Org 52:137-149

de Vincentiis M, Renzoni A (1963) Sulla presenza di uno sporozoo in ovociti di Mytilus galloprovincialis Lam. Arch Zool Ital 47:21-26

FAO (2000) Fishstat Plus: universal software for fishery statistical time series. Version 2.3. Fisheries Department, Fishery Information, Data and Statistics Unit, FAO, Rome

Farley CA (1977) Neoplasms in estuarine mollusks and approaches to ascertain causes. Ann NY Acad Sci 298: $225-232$

Field IA (1923) Biological and economic value of the sea mussel Mytilus edulis. Bull Wash Bur Fish (1921-1922) 38: $127-259$

Figueras AJ, Jardón CF, Caldas JR (1991) Diseases and parasites of rafted mussels (Mytilus galloprovincialis Lmk): preliminary results. Aquaculture 99:17-33

Fries I, de Ruijter A, Paxton RJ, da Silva AJ, Slemenda SB, Pieniazek NJ (2001) Molecular characterization of Nosema bombi (Microsporidia: Nosematidae) and a note on its sites of infection in Bombus terrestris (Hymenoptera: Apoidea). J Apicult Res 40:91-96

Jensen KT, Fernández Castro N, Bachelet G (1999) Infectivity of Himasthla spp. (Trematoda) in cockle (Cerastoderma edule) spat. J Mar Biol Assoc UK 79:265-271

Jones JB (1981) A new microsporidium from the oyster Ostrea lutaria in New Zealand. J Invertebr Pathol 38:67-70

Jonsson PR, André C (1992) Mass mortality of the bivalve Cerastoderma edule on the Swedish west coast caused by infestation with the digenean trematode Cercaria cerastodermae I. Ophelia 36:151-157

Léger L, Hollande AC (1917) Sur un nouveau protiste à facies de Chytridiopsis, parasite des ovules de l'huître. CR

Editorial responsibility: Albert Sparks,

Seattle, Washington, USA
Séances Soc Biol Paris 80:61-64

Lohrmann KB, Feist SW, Brand AR (2000) Microsporidiosis in queen scallops (Aequipecten opercularis L.) from UK waters. J Shellfish Res 19:71-75

Pasharawipas T, Flegel TW, Chaiyaroj S, Mongkolsuk S, Sirisinha S (1994) Comparison of amplified RNA gene sequences from microsporidian parasites (Agmasoma or Thelohania) in Penaeus merguiensis and P. monodon. Asian Fish Sci 7:169-178

Robledo JAF, Santarém MM, Figueras AJ (1994) Parasite loads of rafted blue mussels (Mytilus galloprovincialis) in Spain with special reference to the copepod, Mytilicola intestinalis. Aquaculture 127:287-302

Rybakov AV, Kholodkovskaya EV (1987) Parasites and commensals of the mussel Mytilus galloprovincialis in the northwest Black Sea. Biol Morya 2:22-29

Sagristà E, Bozzo MG, Bigas M, Poquet M, Durfort M (1998) Developmental cycle and ultrastructure of Steinhausia mytilovum, a microsporidian parasite of oocytes of the mussel, Mytilus galloprovincialis (Mollusca, Bivalvia). Eur J Protistol 34:58-68

Scherrer B (1984) Biostatistique. Gaëtan Morin Editeur, Chicoutimi

Shaw BL, Battle HI (1957) The gross and microscopic anatomy of the digestive tract of the oyster Crassostrea virginica (Gmelin). Can J Zool 35:325-347

Sprague V (1965) Observations on Chytridiopsis mytilovum (Field), formerly Haplosporidium mytilovum Field (Microsporida?). J Protozool 12:385-389

Sprague V (1970) Some protozoan parasites and hyperparasites in marine bivalve molluscs. In: Snieszko SF (ed) A symposium on diseases of fishes and shellfishes. Special publication 5. American Fisheries Society, Washington, DC, p 511-526

Villalba A, Carballal MJ, López MC (1993a) Pathologic conditions of three carpet shell clam species of Galicia (NW of Spain). Spec Publ Eur Aquacult Soc 19:85

Villalba A, López MC, Carballal MJ (1993b) Parasitos y alteraciones patologicas de tres especies de almeja, Ruditapes decussatus, Venerupis pullastra, y Venerupis rhomboides, en las rias gallegas. In: Cervino A, Landin A, de Coo A, Guerra A, Torre M (eds) Actas del IV Congreso Nacional de Acuicultura. Centro de Investigaciones Marinas, Pontevedra, p 551-556

Villalba A, Mourelle SG, Carballal MJ, López C (1997) Symbionts and diseases of farmed mussels Mytilus galloprovincialis throughout the culture process in the Rías of Galicia (NW Spain). Dis Aquat Org 31:127-139

Submitted: March 19, 2003; Accepted: August 16, 2003

Proofs received from author(s): November 7, 2003 